\title{
PERFORMANCE OF TWO TYPES OF CEMENT IN PRODUCTION OF CEMENT BONDED WOOD PANELS COMBINED WITH RICE HULL
}

\author{
Rafael da Rosa Azambuja ${ }^{1}$, Daniela Silva Lilge ${ }^{2}$, Elio José Santini ${ }^{3}$, Clovis Roberto Haselein ${ }^{3}$ \\ ${ }^{1}$ Forest Engineer. MSc, UFPR, Curitiba, PR, Brazil - rafael.r.azambuja@gmail.com. \\ ${ }^{2}$ Forest Engineer, M.Sc., Department of Forest Engineering, UNIPAMPA, São Gabriel, RS, Brazil - danielalilge@gmail.com \\ ${ }^{3}$ Forest Engineer, Dr., Department of Forest Sciences, UFSM, Santa Maria, RS, Brazil - ejsantini@ gmail.com; \\ clovis.haselein@ufsm.br
}

Received for publication: 22/10/2013 - Accepted for publication: 09/04/2014

\begin{abstract}
The objective of this study was to evaluate the performance of two types of cement in the manufacturing of cement bonded wood panels with addition of rice hull. Sealers used were cement VARI (CP V) and cement Portland IV, pozzolanic (CP IV). Proportions adopted in the composition of panels were 0, 50 and $100 \%$ rice hulls combined with 100, 50 and $0 \%$ of wood particles. Species used in this study were Eucalyptus grandis and Pinus elliottii. Parameters considered to evaluate panels were the mechanical properties. CP IV did not cure with the addition of pine particles in any proportion. The values of modulus of rupture (MOR) were higher with $\mathrm{CP}$ IV, but with the addition of rice hulls they decreased. CP V shoved higher internal bond strength in all proportions studied. Addition of rice hulls decreased all the mechanical properties studied in this work, therefore its use in cement bonded wood panels must be controlled, larger quantities than $50 \%$ of total vegetal mass weight are not recommended. Using Bison process as a reference, CP IV presented the necessary requirements to be used in cement bonded wood panels.

Keywords: Eucalyptus grandis; CP IV; CP V-ARI; agricultural waste.
\end{abstract}

\section{Resumo}

Desempenho de dois tipos de cimentos na produção de painéis cimento madeira combinados com casca de arroz. O objetivo deste trabalho foi avaliar o desempenho de dois tipos de cimento na manufatura de painéis cimento madeira com adição de casca de arroz. Os cimentos avaliados foram o cimento Portland V - ARI (CP V) e o cimento Portland IV, pozolânico (CP IV). As proporções usadas na composição dos painéis foram de 0,50 e $100 \%$ de casca de arroz combinadas com 100,50 e $0 \%$ de partículas de madeira, sendo as espécies utilizadas Eucalyptus grandis e Pinus elliottii. Os parâmetros utilizados para avaliar os painéis foram as propriedades mecânicas. O CP IV não foi capaz de curar com a adição das partículas de pinus em nenhuma proporção. Os valores de módulo de ruptura (MOR) foram maiores com o CP IV, porém com adição de casca de arroz estes foram decrescendo. $\mathrm{O}$ CP V apresentou maiores valores de ligação interna para todas as proporções estudadas. A adição da casca de arroz diminuiu todas as propriedades estudadas neste trabalho portanto a sua utilização em painéis cimento madeira deve ser controladas e não aconselhadas em quantidades maiores que 50\% do peso da massa vegetal utilizada. Usando o processo Bison como referência, o CP IV apresentou os requerimentos necessários para uso como painéis cimento madeira.

Palavras-chave: Eucalyptus grandis; CP IV; CP V-ARI; resíduo agrícola.

\section{INTRODUCTION}

Studying and understanding the basic structures used in small and big constructions is essential for optimization and natural evolution of the civil construction methodologies. A new growing niche in civil construction is represented by renewable materials, and among these possibilities there is a wider use of wood as a substitute of other basic components.

Cement bonded wood panels gather desirable properties of both materials (LIPINSKI, 1994), like tensile strength, low density and flexural strength derived from wood particles, together with flame retardant characteristics, resistance to insects and small variation of humidity, deriving from cement. It is 
also highlighted their resistance to fire, to fungi and termite attacks and their good acoustic insulation properties (LATORRACA et al., 1999).

For these reasons, according to Chapola (1989), cement bonded wood panels have more applications than conventional panels, and this kind of product deserves technological improvements derived from researches. Besides its applications in civil construction, there are indications that this type of panels is widely used for walls, floors and linings (OKINO et al., 2003).

According with data of the Brazilian Institute of Geography and Statistics (Instituto Brasileiro de Geografia e Estatistica) (IBGE, 2012), in 2011 Brazil produced approximately 13.44 millions of tons of paddy rice, which gives around 2.64 millions of tons of rice hulls, keeping in mind that rice hulls represent around 20\% of paddy rice weight. (AMICK, 1982). Good part of this residual ends up in production of energy, which is not controlled and could cause environmental impacts for large scale rice production regions, like, for example, southern Brazil. A solution to this problem is rice hull treatment as a sub-product that should be used in its basic form and not in ash form.

Rice hull ash combined with cement is already considered viable by various authors (GANESAN et al., 2008, CHINDAPRASIRT et al., 2008). Rice hull, just like rice hull ash, is known to have silica in its composition, which is a pozzolanic agent with influence on cement curing (KAMIYA et al., 2000). This alternative bonding agent may, through pozzolanic adjunctions, reduce alkalinity and calcium hydroxide content, avoiding long time decay of the vegetal material in cement bonded wood materials (TORKAMAN et al., 2014).

In the same way, calcium silicate hydrate is a component that can be obtained from rice hull, being this material the main product of normal Portland cement hydration. Rice hull is a pozzolanic material and can be used as a supplementary cement material to substitute Portland cement up to $30 \%$ (GANESAN et al., 2008). Benefits of rice hull ash added to cement are the following: economic gain from substitution of a substantial portion of Portland cement with a less expensive material and improvement of the final product durability (CHATVEERA; LERTWATTANARUK, 2009).

Addition of unburned rice hull in cement composites has already been tested by some authors, among whom can be cited the works by Zucco (1999), Beraldo and Zucco (1998), and Rossi et al. (2005), where potentiality of this material was observed, however still without testing its use together with wood fibers.

Considering the types of cement, the different definitions of Portland cement are given depending on the additives in their composition. According to definition of Associação Brasileira de Cimento Portland (ABCP, 2012), additions to cement are other raw matters added in the clinker during the milling phase, which allow fabrication of the different types of Portland cement available in the market.

The most common wood and cement proportion used, inclusive in the industrial process, is 1:2.75. Other greater or smaller ratios have been tested, however as long as the wood content increases with respect to cement, curing time of panels gets longer (LATORRACA; IWAKIRI, 2000). With the objective of a more efficient production chain, researches with CP V-ARI for rapid curing are the most common. However, studies aimed to test other types of cement must be conducted to have a better understanding of the relationships between wood and cement. This because a type of cement could reduce curing and hardening time, while another could reduce initial costs of the process.

Despite the promising characteristics for their use in civil construction, there are still some limitations in the fabrication process of cement bonded wood panels. The main limitation is that wood fibers of some species are incompatible with cement, due to presence of some chemical substances (carbohydrates and tannins). These substances cause delay in cement hardening, impairing the resulting characteristics of panels (SIMATUPANG et al., 1978; MOSLEMI; AHN, 1980). Hofstrand et al. (1984) describes that, according to several authors, the effect of wood on cement is depending on various factors, including geographical localization, species and the different substances they contain.

A commonly used methodology to evaluate limitations of a species, in cement bonded wood panels, starts from the inhibition index. In this test, inhibition to cement curing due to wood presence is assessed through monitoring cement temperature for 24 hours. Temperature of the chemical reaction indicates curing velocity and capability, so that to assess if inhibition is taking place, two temperature versus time curves are generated, one of cement without wood and another of the composition of wood and cement. These two curves are compared and the lower is the difference between them, the smaller is 
the inhibition effect due to presence of wood. In some cases can be observed that wood components have such strong influence on cement reaction that curing results impossible.

Some works are worth to be cited about incompatibility of genus Pinus wood with cement. In the study by Latorraca et al. (1999) about inhibitory effect of forest species on cement curing, it was concluded that, considering Portland II cement, the inhibitory effect of Pinus taeda was bigger than the one of Eucalyptus citriodora Hook., although both were considered with low inhibitory index.

Alberto et al. (2000), in a study about inhibition of cement curing caused by native species in Mozambique, keeping Pinus wood as control, confirmed that inhibition behavior depends on the type of cement used. This author used the compatibility factor (Cf), which is the ratio between liberation of energy in cement reaction and liberation of energy in wood cement composite (Qc/Qp). In this study the author obtained, with rapid reaction cement, $\mathrm{Cf}=94 \%$ with Pinus elliotti wood and $\mathrm{Cf}=93 \%$ with Pinus patula Scheide et Deppe., while using a slower reaction cement observed $\mathrm{Cf}=83 \%$ and $29 \%$ with Pinus elliotti and Pinus patula, respectively, proving that the type of cement also has influence on the inhibition index.

In the same way, the research by Zucco (1999) on viability of cement boards with rice hull, affirms that particle size of rice hulls and the type of cement used have influence on the hydration curve of the composition. Thus, the smaller the particle the greater is the inhibitory effect, increasing the time needed for temperature to reach its peak. In the same work was also determined that the best cement for cement boards with rice hulls is Portland V - ARI.

Govin et al. (2006), studying ways to improve hydration of cement bonded wood materials, affirmed that one possibility is to pre-treat wood with heat. In this study was observed that high temperature treatments provide hygroscopicity and dimensional stability improvements of Alamo wood, thus the author improved hydration of cement composites and reduced its consumption.

The inhibition effect can be avoided or minimized by treating the lignocellulosic material particles, by using a more adequate or less sensible cement type to be combined with the lignocellulosic material, or by the addition of chemical and mineral additives (BERALDO et al., 2002). It is worth to highlight that chemical and mineral additives are applied with the objective to accelerate cement curing.

The most common chemical additives used are calcium chloride, sodium silicate and sodium hydroxide, in quantities varying from $3 \%$ to $5 \%$ of the cement weight (LATORRACA, 1996). Among the treatments with additives, in a study on compatibility between cement and tropical species, Fan et al. (2012), assessed different pre-treatments, with $\mathrm{Ca}(\mathrm{OH})_{2}, \mathrm{MeOH}, \mathrm{H}_{2} \mathrm{O}$ and $\mathrm{CaCl}_{2}$. Out of the above described treatments, the solution of calcium hydroxide, $\mathrm{Ca}\left(\mathrm{OH}_{2}\right)$, resulted in improved compatibility between wood and cement, better than with the other pre-treatments.

Thus, this work aims to study the quality of cement bonded wood panels, produced with two types of cement combined with different proportions of rice hulls. Quality of panels will be assessed by mechanical tests proposed by the American Society for Testing and Materials (ASTM) D-1037, (1999). Particular characteristics of the two cements, characteristics of the two forest species used and the interaction with additions of rice hulls in the composite, were studied as the specific objectives of this study.

\section{MATERIAL AND METHODS}

In this work was used the methodology described by Lilge (2009). Wood particles used in the development of this study were from the species Eucalyptus grandis W. Hill ex Maiden and Pinus elliottii Engelm. Cements assessed were Portland V-ARI-RS and Portland IV pozzolanic. Furthermore, there was addition of rice hulls, besides additives and water, for the production of panels.

Eucalyptus grandis particles were obtained by the sawing process of trees from a homogeneous forest stand approximately 15 years old, located in the Campus of Universidade Federal de Santa Maria. Pinus elliottii particles were supplied by the company Todesmade, from its carpentry department, located in the municipality of Cachoeira do Sul, RS. Particles of both species were crushed in a minder and grinded in a hammer mill reducing their dimensions at the point they could be sifted in a $0.6 \mathrm{~mm}$ net sieve, with the objective to obtain a more homogeneous material. Final dimensions of particles were from $6 \times 8 \times 0.3 \mathrm{~mm}$ to $23 \times 15 \times 0.8 \mathrm{~mm}$. 
Rice hulls were supplied by Guidolin Mills in Santa Maria, RS. They were grinded in a hammer mill, with $8 \mathrm{~mm}$ sieve. Thereafter, were sifted in a $0.6 \mathrm{~mm}$ net siege to eliminate smaller residuals. Final phase of rice hulls preparation consisted in washing in lime $\mathrm{Ca}\left(\mathrm{OH}_{2}\right)$ solution, as proposed by Serrano and Castro (1985) and Bertaldo and Zucco (1998). Following the methodology of the cited authors, quantity of lime used was $5 \%$ of the total rice hull mass treated, and ratio between lime solution and rice hull was 10:1.

Cements assessed in this work are defined by the following specifications by ABCP (2012): CP IV-Pozzolanic: 45-84\% Clinker + Plaster, 15-50\% Pozzolanic Material, 0-5\% limestone; CP V-ARI: 95100\% Clinker + Plaster, 0-5\% Limestone.

Tabela 1. Dimensões e composição dos painéis manufaturados.

Table 1. Dimensions and composition of the manufactured panels.

\begin{tabular}{lc}
\hline & Data of panels \\
\hline Width $(\mathrm{cm})$ & 50 \\
Length $(\mathrm{cm})$ & 50 \\
Thickness $(\mathrm{cm})$ & 0.95 \\
Density $\left(\mathrm{g} / \mathrm{cm}^{3}\right)$ & 1.25 \\
Ratio of vegetal biomass: cement & 0.364 \\
Ratio of hydration water: cement & 0.25 \\
Ratio of water: cement & 0.45 \\
Ratio of additive: cement & 0.03 \\
Biomass humidity content $(\%)$ & 12.3 \\
\hline
\end{tabular}

Tabela 2. Delineamento dos tratamentos utilizados para as diferentes proporções madeira e casca de arroz com dois cimentos diferentes.

Table 2. Delineation of treatments applied with different proportions of wood and rice hull with two different cements.

\begin{tabular}{lcccc}
\hline \multirow{2}{*}{ Treatment } & \multirow{2}{*}{ Cement } & \multicolumn{3}{c}{ Vegetal material proportion } \\
\cline { 3 - 5 } & CP IV & 0 & Pucaliptus (\%) & Rice hull (\%) \\
\hline T1 & CP V & 0 & 100 & 0 \\
T2 & CP IV & 0 & 500 & 0 \\
T3 & CP V & 0 & 50 & 50 \\
T4 & CP IV & 0 & 0 & 100 \\
T5 & CP V & 0 & 0 & 100 \\
T6 & CP V & 100 & 0 & 0 \\
T7 & CP IV & 100 & 0 & 0 \\
T8 & CP V & 50 & 0 & 50 \\
T9 & CP IV & 50 & 0 & 50 \\
T10 &
\end{tabular}

Where: CP IV: Portland Cement IV (pozzolanic); CP V: Portland Cement V-ARI; (\%) of total vegetal material in the panel.

Additive used was dehydrate calcium chloride $\left(\mathrm{CaCl}_{2}+2 \mathrm{H}_{2} \mathrm{O}\right)$, which works as catalyzer in cement curing. After measuring all the components of the panels, fabrication started using a concrete mixer. Next, mixed material was put in molds and then on metal boards to shape dimensions, and then put into a hydraulic press. Components content of panels and their dimensions are presented in table 1 . The experimental design of treatments is shown in table 2.

Three panels were put in the press at the same time, and a force of $15 \mathrm{kgf} / \mathrm{cm}^{2}$ was applied for 24 hours, curing of panels was performed in cold. During the pressing process, lateral iron tutors were used, to ensure that thickness was going to be uniform and consistent in all manufactured panels. To complete acclimatization, panels were taken into a climatic room, with $60 \%$ humidity and $20^{\circ} \mathrm{C}$ temperature, to complete the curing process.

A period of 28 days was given for cement curing and then panels were reduced to specimen dimensions, defined together with the type of tests applied according to ASTM D-1037, (1999). To reach 
a greater accuracy of the tests, specimen were collected from different positions and from the entire extension of the panels.

After acclimatization, specific mass of each specimen was measured. This property was obtained through measure of specimen dimensions, in centimeters, and their weight in grams. Knowing the specimen volume, ratio between weight and volume gave density of panels.

Mechanical tests performed were: static bending test, to determine modulus of elasticity (MOE) and modulus of rupture (MOR), internal bond (IB) and screw pullout test (SP), performed on the universal test bench of Forest Products Laboratory, Universidade Federal de Santa Maria. Three panels were produced for each treatment, totalizing 9 replicates for bending and screw pullout tests, and 12 replicates for internal bond tests.

Results of the performed tests were then tabulated and submitted to statistical analyses, with significance of differences between their means verified by Tuckey range test, at $95 \%$ level of probability.

\section{RESULTS AND DISCUSSIONS}

No one of the panels manufactured with Portland IV cement, with any pine proportion in their composition, reached the minimum stiffness level for the tests. Thus it is clear that Pinus elliottii wood was incompatible with Portland IV cement. Therefore, because of lack of parameters to compare viability of panels in function of cement, a new experimental design was defined taking away all treatments with pine wood addition and the only treatments considered were then from 1 to 6 , presented in table 2 . Results of mechanical tests are presented in table 3.

Among the possible reasons for unsuccessful curing of Portland IV cement with genus Pinus wood, it is possible to cite the work by Latorraca et al. (1999), where the greater inhibition effect of genus Pinus compared to genus Eucalyptus was observed. Another already cited researcher, Alberto et al. (2000), indicated that when Pine wood is added, slower reaction cement tends to have a greater reaction temperature reduction. These studies corroborate the complexity of compatibility between pine wood and cement.

In this work, size of rice hull particles vary from 6 to $8 \mathrm{~mm}$, in the cited work by Zucco (1999), particles varied from 3 to $10 \mathrm{~mm}$, thus it may be assumed that size of particles could also have created interference with the cement curing process.

There are promising pre-treatments to avoid wood inhibition effects, Govin et al. (2006) proposed a thermic pre-treatment of wood, where heat increases hygroscopicity and dimensional stability. Another pre-treatment that may be indicated for future works is particle washing with calcium hydroxide, because according to Parchen (2012), this pre-treatment reduces the Pinus wood inhibition effect on cement curing. There is also the possibility to wash particles with cold or hot water, cited by Beraldo $e t$ al. (2000), and Latorraca and Iwakiri (2000). These kind of pre-treatments may be applied in future studies, in order to verify improvements in panel curing when they are manufactured with pine wood and Portland IV cement.

Panels that did not present curing problems were submitted to physical and mechanical tests, whose results are presented in table 3, such as comparison of their means by the Tuckey range test at $95 \%$ level of probability.

Tabela 3. Resultados dos testes mecânicos para os diferentes tratamentos.

Table 3. Results of mechanical tests on the different treatments.

\begin{tabular}{|c|c|c|c|c|c|}
\hline \multirow[t]{2}{*}{ Treatments } & \multirow{2}{*}{$\begin{array}{l}\text { Specific mass } \\
\quad\left(\mathrm{g} / \mathrm{cm}^{3}\right)\end{array}$} & \multirow{2}{*}{$\frac{\text { Tensile }}{\text { IB }\left(\mathrm{kgf} / \mathrm{cm}^{2}\right)}$} & \multicolumn{2}{|c|}{ Static bending } & \multirow{2}{*}{$\begin{array}{c}\begin{array}{c}\text { Screw pullout } \\
\text { parafuso }\end{array} \\
\text { Load (kgf) } \\
\end{array}$} \\
\hline & & & $\operatorname{MOR}\left(\mathrm{kgf} / \mathrm{cm}^{2}\right)$ & MOE $\left(\mathrm{kgf} / \mathrm{cm}^{2}\right)$ & \\
\hline $\mathrm{T} 1$ & 1.14 & $7.35 \mathrm{~b}$ & $150.98 \mathrm{a}$ & $35428 \mathrm{a}$ & $130.89 \mathrm{a}$ \\
\hline $\mathrm{T} 2$ & 1.17 & $9.38 \mathrm{a}$ & $121.53 \mathrm{~b}$ & $24692 \mathrm{ab}$ & $131.22 \mathrm{a}$ \\
\hline $\mathrm{T} 3$ & 1.26 & $3.92 \mathrm{~d}$ & $70.87 \mathrm{c}$ & $18881 \mathrm{~b}$ & $108.22 \mathrm{~b}$ \\
\hline $\mathrm{T} 4$ & 1.27 & $5.31 \mathrm{c}$ & $78.61 \mathrm{c}$ & $19999 \mathrm{~b}$ & $87.33 \mathrm{c}$ \\
\hline T5 & 1.30 & $1.53 \mathrm{e}$ & $43.41 \mathrm{~d}$ & $14648 \mathrm{~b}$ & $56.89 \mathrm{~d}$ \\
\hline T6 & 1.27 & $4.04 \mathrm{~d}$ & $65.56 \mathrm{c}$ & $14138 \mathrm{~b}$ & $79.22 \mathrm{c}$ \\
\hline
\end{tabular}

*IB: internal bond; MOE: modulus of eleasticiy; MOR: modulus of rupture. ${ }^{* *}$ Same letters in the same column have no significant difference between them by Tuckey range test at $95 \%$ of probability. 
Specific mass of panels varied from $1.14 \mathrm{~g} / \mathrm{cm}^{3}$ to $1.30 \mathrm{~g} / \mathrm{cm}^{3}$, while the expected value was 1.25 $\mathrm{g} / \mathrm{cm}^{2}$. Variations of specific mass between and inside bonded panels were expected, they are originated by the manual manufacturing process that took place in the laboratory. Lack of homogeneity in manual distribution of the mixture to form boards is a recurrent factor and it is found in works of this kind (HILLIG, 2000; DACOSTA, 2004; LILGE, 2009).

In the perpendicular tensile strength test (IB), Portland V-ARI cement obtained the best results, with variations due to rice hull. It was noticed that increasing of rice hull content in the panel resulted in a decreased perpendicular tensile strength. Latorraca (1996), analyzing performance of cement bonded wood boards made with particles of Eucalyptus dunnii Maiden, found IB values from 0.37 to 1.22 $\mathrm{kgf} / \mathrm{cm}^{2}$. Ordinary cement was used in the experiment by this author, thus results were less satisfactory than the ones of this work.

Modulus of Elasticity results (MOE), obtained during the static bending test, did not show great differences depending on the type of cement used, but mostly depending on the rice hull content added to panels. Boards manufactured with CP IV cement presented higher values, although without significant differences with panels made with CP V cement. As the rice hull content increased, MOE decreased until reached the lowest value corresponding to the greatest rice hull percentage added, although still without significant differences from the intermediate treatments, according to the statistical test applied.

Latorraca (1996), working with cement bonded wood materials with Eucalyptus dunnii and using $\mathrm{CaCl}_{2}$ as additive, verified MOE values between 24083 and $29178 \mathrm{kgf} / \mathrm{cm}^{2}$, values similar to the ones registered in this study, taking into consideration the proportion of components in panels and the used methodology.

Modulus of Rupture (MOR) values, obtained by the static bending test, showed greater variations between treatments, from 43 to $150 \mathrm{kgf} / \mathrm{cm}^{2}$. CP V cement gave best results with the different rice hull proportions in its composition. However, in treatments composed only with eucalyptus, without rice hull addition, cement CP IV gave the best result of all, reaching $150 \mathrm{kgf} / \mathrm{cm}^{2}$ of mean value.

In treatments of cement bonded wood panels with pine and rice hull particles, Lilge (2009) found MOR values from 99.85 to $61.72 \mathrm{kgf} / \mathrm{cm}^{2}$, indicating that use of cement Portland IV has a positive effect on MOR. Again about MOR and additives used in this research, it is worth to mention studies by Latorraca (1996), indicating that the use of additives like $\mathrm{CaCl}_{2}$ and $\mathrm{MgCl}_{2}$ produce better MOR performance in panels, compared to treatments where wood particles were washed with water only.

Iwakiri and Prata (2008), studying viability of different eucalyptus species for cement bonded wood materials, in the case of Eucalyptus grandis without treatment, found approximately the following values: IB $4.79 \mathrm{kgf} / \mathrm{cm}^{2}$, MOR $48732 \mathrm{kgf} / \mathrm{cm}^{2}$ and MOE $100.9 \mathrm{kgf} / \mathrm{cm}^{2}$. Considering that density used was similar to this study and that cement used was CP V-ARI, some comparisons can be made, like for example the confirmation of good strength from T1, which is composed by CP IV. Taking into consideration that the cited author affirms potential of the species for cement bonded wood panels, it may also be considered that T1, with Portland IV cement, has great potential for the same purpose.

The worst MOE and MOR performances were observed in panels made only with cement and rice hull, indicating that mixture of this material in cement bonded wood panels may weaken resistance of manufactured boards, its addition has tendency to create a lower strength in panels.

Mean values observed in tensile strength and screw pullouts tests (SP) varied from 56.88 to 131.22 kgf. El-Juhany et al. (2003), studying cement bonded wood panels made from agricultural residues, found mean values of $83 \mathrm{kgf}$ for screw pullout test in panels with approximately $1 \mathrm{~g} / \mathrm{cm}^{3}$ density, made with oak trees sawdust and Portland type I cement. Despite particularities of each work, results indicate that panels with $50 \%$ of rice hull in this work obtained adequate performances, similar to what found by the cited author.

The use of Portland CP V cement gave greater strength in screw pullout tests, compared to cement CP IV. However, results were different also with respect to panel composition in particles content. Addition of rice hull weakened the composite, such that SP values diminished as the percentage of rice hull increased.

Requirements established by the Bison (1978) process are values of IB, MOR and MOE above $0.4 \mathrm{Mpa}\left(4.08 \mathrm{kgf} / \mathrm{cm}^{2}\right), 9 \mathrm{Mpa}\left(91.77 \mathrm{kgf} / \mathrm{cm}^{2}\right)$, and $3000 \mathrm{Mpa}\left(30591 \mathrm{kgf} / \mathrm{cm}^{2}\right)$, respectively, are the minimum necessary properties of a good quality cement bonded wood panel. These values were given only by T1 (100\% Eucalyptus grandis with CP IV). T2 had only insufficient MOE values, thus indicating 
that Portland V cement with Eucalyptus grandis is not indicated for the production of this type of panels, until a way to obtain MOE improvements will be found. CP IV with Eucalyptus grandis addition, according to the methodology described in this study, has potential to be used according to the described literature.

Generally speaking, it is possible to observe that treatments where there was addition of rice hull obtained the worst results in the performed tests. However, its use in small proportions is justified, not significantly affecting the physical and mechanical properties of panels and at the same time allowing wood content reduction, which is a more expensive material, and permitting also exploitation of a residual raw matter produced in great quantities in the country. Still, Portland IV cement, despite showing problems with curing, obtained good mechanical results and for this reason more studies are needed with this cement, inclusive with wood particles pre-treatments.

\section{CONCLUSIONS}

- Considering the results obtained in this study, it is possible to conclude that with relation to the types of cement, species and rice hull:

- Pinus elliottii wood without adequate pre-treatments does not allow curing of Portland IV cement. For future studies is suggested the implementation of particles pre-treatments when using CP-IV.

- Internal bond of panels made with Portland V cement was greater than IB of panels made with Portland IV cement. Still considering IB of panels, addition of rice hull reduced this strength, which was even lower in case of CP-IV cement, indicating worst compatibility between rice hull particles and this type of cement;

- MOE values showed no differences depending on the cements used, addition of rice hull reduced strength of this property;

- Considering MOR values, CP-IV showed greater strength than CP-V, although CP-IV showed greater variations between treatments. Addition of rice hull in the panel reduced MOR values.

- Screw pullout strength compared between cements did not show statistically significant differences, addition of rice hull reduced this property.

- Addition of rice hull is not suggested above $50 \%$ of the total vegetal material in cement bonded wood panels.

\section{REFERENCES}

ALBERTO, M. M.; MOUGEL, E.; ZOULALIAN, A. Compatibility of some tropical hardwoods species with Portland cement using isothermal calorimetry. Forest Products Journal, v. 50 (9) p. 83 - 88, 2000.

ASSOCIAÇÃO BRASILEIRA DE CIMENTO PORTLAND. Básico sobre cimento. Disponível em <http://www.abcp.com.br>. Acesso em: dezembro 2012.

AMERICAN SOCIETY FOR TESTING AND MATERIALS (ASTM). Standard test methods for evaluating properties of wood-base fiber and particle panel materials. D 1037 - 99. v. 04.10 on Wood Book of ASTM Standard. ASTM. West Conshohocken, 1999.

AMICK, J. A. Purification of rice hulls as a source of solar grade silicon for solar cells. Journal of The Electrochemical Society, Pennington, v. 129, n. 4, p. 864 - 866, 1982.

BERALDO, A. L.; ZUCCO, L. L. Compósitos à base de cimento Portland: estudos efetuados para viabilizar o uso da casca de arroz. In: BALBUENA, R. H.; BENEZ, S. H.; JORAJURIA, D. Ingenieria rural y mecanización agraria en el ámbito latino americano. $1^{\text {a }}$ ed. La Plata: UNLP, 1998, p. 479 488.

BERALDO, A. L.; LOPES, W. G. R; CARVALHO, J. V.; ARZOLLA, J. A. P. R.; SEVEGNANI, K.; SOUZA, P. Efeito da espécie vegetal do tipo de cimento e do tratamento utilizado sobre a resistência à compressão de compósitos. In: ENCONTRO NACIONAL DE TECNOLOGIA DO AMBIENTE CONSTRUÍDO, 8., 2000, Salvador. Anais...Salvador: [s.n], 2000. 1 CD - ROM. 
BERALDO, A. L; ARRUDA, A. C.; STANCATO, A. C.; SAMPAIO, C. A. P.; FERNANDES FILHO, O. P.; LEONEL, V. M. Compósito à base de resíduos vegetais e cimento Portland. In: VIII ENCONTRO BRASILEIRO EM MADEIRA E EM ESTRUTURAS DE MADEIRA, 8, Uberlândia, 2002. Anais... Uberlândia: UFU, 2002. p. 85 - 90.

BISON Wood-cement board. New York. Springer, 1978. 10 p.

CHAPOLA, G. B. J. Effect of curing heat, alkali and cement set in cement particleboard on the viscoelastic properties of chip mattresses. Wood Science and Technology, v. 23, p. 131 - 138, 1989.

CHATVEERA, B.; LERTWATTANARUK, P. Evaluation of sulfate resistance of cement mortars containing black rice husk ash. Journal of Environ Manage, v. 90, Rushden, p. 1435 - 1441, 2009.

CHINDAPRASIRT, P.; RUKZON, S.; SIRIVIVATNANON, V. Effect of carbon dioxide on chloride penetration and chloride ion diffusion coefficient of blended Portland cement mortar. Construction and Building Materials, Rushden, v. 22, n. 8, p. 1607 - 1701, 2008.

DACOSTA, L. P. E. Utilização de resíduos do processamento mecânico da madeira para fabricação de chapas aglomeradas. 188 f. Dissertação (Mestrado em Engenharia Florestal) - Universidade Federal de Santa Maria, Santa Maria. 2004.

EL-JUHANY, L. I.; AREF, I.M.; WAKEEL, A. O. Evaluation of using some available lignocellulosic agricultural residues in manufacturing wood-cement boards in Saudi Arabia. In: INTERNATIONAL CONFERENCE ON DATE PALM, 2003, Date Palm. Proceedings... Buraidah, 2003. p. 281 - 291.

FAN, M.; NDIKONTAR, M. K.; ZHOU, X.; NGAMVENG, J. N. Cement-bonded composites made from tropical woods: Compatibility of wood and cement. Construction and Building Materials, Rushden, v. 36, p. 135 - 140, 2012.

GANESAN, K.; RAJAGOPAL, K.; THANGAVEL, K. Rice husk ash blended cement: assessment of optimal level of replacement for strength and permeability properties of concrete. Construction and Building Materials, Rushden, v. 22, n. 8, p. 1675 - 1683, 2008.

GOVIN, A.; PESCHARD, A.; GUYONNET, R. Modification of cement hydration at early ages by natural and heated wood. Cement \& Concrete Composites, Rushden, v. 28, p. 12 - 20, 2006.

HILLIG, E. Qualidade de chapas aglomeradas estruturais, fabricadas com madeiras de Pinus, Eucalipto e Acácia-negra, puras ou misturadas, coladas com tanino-formaldeído. 96 f. Dissertação (Mestrado em Engenharia Florestal) - Universidade Federal de Santa Maria, Santa Maria, 2000.

HOFSTRAND, A. D., MOSLEMI, A. A., GARCIA, J. F. Curing characteristics of wood particles from nine northern Rocky Mountain species mixed with Portland cement. Forest Product Abstract. v. 34, n. 2, p. $57-61,1984$.

INSTITUTO BRASILEIRO DE GEOGRAFIA E ESTATÍSTICA (IBGE). Levantamento Sistemático da Produção Agrícola. Disponível em: < http://www.ibge.gov.br/home/estatistica/indicadores/ agropecuaria/lspa/estProdAgr_201203.pdf >. Acesso em: 06 dez. 2012.

IWAKIRI, S.; PRATA, J. G. Utilização da madeira de Eucalyptus grandis e Eucalyptus dunnii na produção de painéis cimento-madeira. Cerne, Lavras, v. 14, n. 1, p. 68 - 74, 2008.

KAMIYA, K.; OKA, A.; NASU, H.; HASHIMOTO, T. Comparative study of structure of silica gels from different sources. Journal of Sol-Gel Science and Technology v. 19 p. 495 - 499, 2000.

LATORRACA, J. V. F. Estudo da viabilidade do uso da espécie Eucalyptus dunnii (Maid) na manufatura de painéis de madeira-cimento. 94 f. Dissertação (Mestrado em Ciências Florestais) Universidade Federal do Paraná, Curitiba, 1996.

LATORRACA, J. V. F.; IWAKIRI, S.; LELIS, R. C. C. Efeito Inibidor de Cinco Espécies Florestais Sobre a Cura do Compósito Cimento-Madeira. Floresta e Ambiente, Seropédica, v. 6, n. 1, p. 75 - 82, 1999. 
LATORRACA, J. V. F.; IWAKIRI, S. Efeitos do tratamento das partículas de Eucalyptus Dunnii (maid), da variação da relação madeira-cimento e do uso de aditivos sobre as propriedades físicas e mecânicas de painéis de madeira-cimento. Cerne, Lavras, v. 6, n. 1, p. 68 - 76, 2000.

LILGE, D. S. Desempenho de duas espécies florestais em combinação com casca de arroz na fabricação de painéis cimento-madeira. 90 f. Dissertação (Mestrado em Engenharia Florestal) Universidade Federal de Santa Maria, Santa Maria, 2009.

LIPINSKI, E. Potential technologies for effectively bonding wood with inorganic binders. In.: INTERNATIONAL INORGANIC-BONDED WOOD AND FIBER COMPOSITE MATERIALS CONFERENCE, 1994, Washington. Proceedings... Washington: Spokane, 1994, p. 53 - 58.

MOSLEMI, A. A.; AHN, W. Y. SEM Examination of Wood-Portland Cement Bonds. Wood Science, Japan, v. 13, n. 2, p. 77 - 82, Moscow. 1980.

OKINO, E. Y. A.; SOUZA, M. R.; SANTANA, M. A. E.; ALVES, M. V. S.; SOUSA, M. E.; TEIXEIRA, D. E. Cementbonded wood particleboard with a mixture of eucalypt and rubberwood. Cement \& concrete composites, p. 1 - 6, 2003.

PARCHEN, C. F. A. Compósito madeira cimento de baixa densidade produzido com compactação vibro dinâmica. 172 f. Tese (Doutorado em Engenharia Florestal) - Universidade Federal do Paraná, Curitiba, 2012.

ROSSI, L. A.; CARDOSO, P. E. dos R.; BERALDO, A. L. Avaliação Térmica de Placas de Argamassa de Cimento e Casca de Arroz Aquecidas por Resistência Elétrica. Engenhatia Agrícola, Jaboticabal, v. 25, n. 1, p. 37 - 45, 2005.

SERRANO, J. S.; CASTRO, J. V. Materiales de construcción con propiedades aislantes a base de cascara de arroz. Informes de la Construcción, Madri, v. 37, n. 7, p. 53 - 64, 1985.

SIMATUPANG, M. H.; SCHWARZ, G. H.; BROKER, F. W. Small scale plants for the manufacture of mineral-bonded wood composites. In.: WORLD FORESTRY CONGRESS, 8. Jakarta. Proceedings... Jakarta: Special Paper, 1978, 21 p.

TORKAMAN, J.; ASHORI, A.; MOMTAZIC, A. S. wood fiber waste, rice husk ash, and limestone powder waste as cement replacement materials for lightweight concrete blocks. Construction and Building Materials, Rushden, v. 50, n. 15, p. 432 - 436, 2014.

ZUCCO, L. L. Estudo da viabilidade de fabricação de placas de compósitos à base de cimento e casca de arroz. 118 f. Dissertação (Mestrado em Construções Rurais e Ambiência) - Faculdade de Engenharia Agrícola, Universidade Estadual de Campinas, Campinas, 1999. 
